\title{
A Knowledge Analysis of the Implementation of STEM-Based Learning of Prospective Chemistry Teachers
}

\author{
Viqri Rolanda ${ }^{\mathrm{a}}$, Muhammad Adlim ${ }^{\mathrm{b}^{*}}$, Muhammad Syukri ${ }^{\mathrm{c}}$ \\ ${ }^{a}$ Science Education Study Program, Graduate School, Syiah Kuala University, Banda Aceh, Indonesia \\ ${ }^{\mathrm{b}}$ Department of Chemical Education, Faculty of Teacher Training and Education, Syiah Kuala University, Banda Aceh, Indonesia \\ ${ }^{c}$ Department of Physics Education, Faculty of Teacher Training and Education, Syiah Kuala University, Banda Aceh, Indonesia
}

${ }^{*}$ Corresponding author: Teuku Nyak Arief Street No.441, Kopelma Darussalam, Syiah Kuala, Banda Aceh City, Aceh, 23111, Indonesia. E-mail addresses: adlim@unsyiah.ac.id

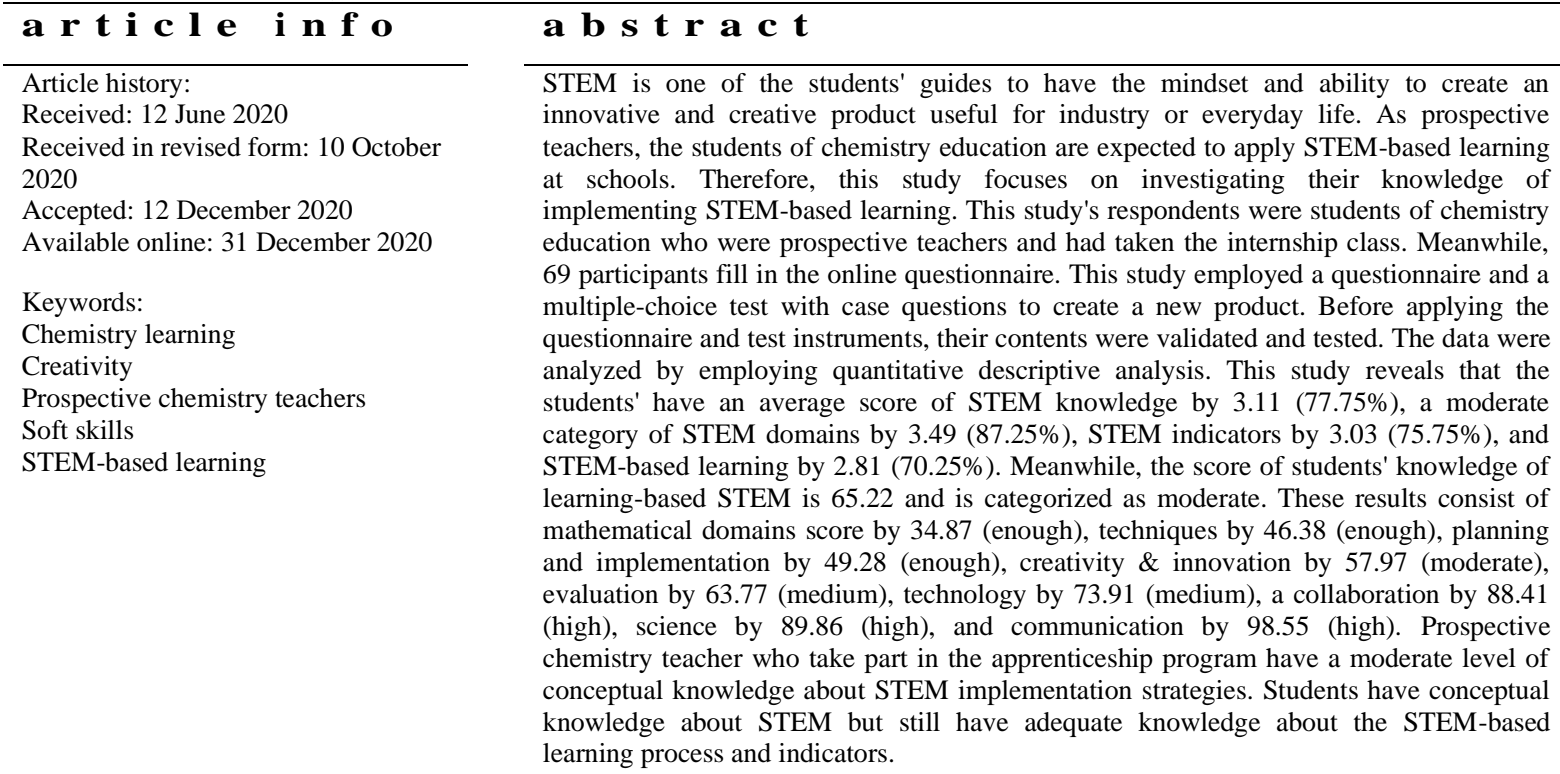

2020 Scientiae Educatia: Jurnal Pendidikan Sains

\section{Introduction}

In recent-global competition, social and economy provide opportunities to create advanced technology-based industrial products. Investments in developing countries are commonly based on advanced technology projects. Therefore, students compulsorily possess human resource competencies required in this century. These competencies include 1) criticalthinking and problem-solving skills, 2) communication and collaboration skills, 3) creativity and innovation skills, 4) information and communication technology literacy, 5) contextual learning skills, and 6) information and media literacy skills. One solution to achieve these competencies is science-based learning, technology, engineering, and mathematical (STEM) (Pimthong \& Williams, 2018). 
STEM has become a learning approach that integrates natural science, technology, engineering, and mathematics in a learning process (Bell, 2015). Many studies proved that STEM is successfully combined with problem-based learning (PBL) to actualize environmental literacy and student creativity (Farwati et al., 2018). Meanwhile, Sari et al. (2018) developed STEM-based student worksheets to test their vocational and regular high schools' effectiveness and discover a positive response. Compared to high schools, vocational high school students have superior motivation to complete STEM project-based tasks because they regard that entrepreneurship can provide high employment opportunities. Adlim et al. (2015) developed an integrated entrepreneurial STEM module and proved that the module could improve students 'science process skills and build their excellent entrepreneurial attitudes. Other researchers demonstrated that STEM could increase motivation and learning activities (Rahmiza et al., 2015), scientific literacy (Ismail et al., 2016; Afriana et al., 2016), and understanding of good content (Al Salami et al., 2015).

Prospective science teachers, including chemistry education students, are required to master STEM-based learning skills. However, not all of them have learned STEM as it is not included in their learning curriculum. Almost all chemistry, physics, biology, and mathematics courses that prospective teachers learn in tertiary institutions are monodisciplinary. Meanwhile, STEM tends to be a multidisciplinary course and emphasizes creativity development exercises. Subjects such as professional education, educational psychology, environmental chemistry, instructional media, colloquium, and food chemistry have supported prospective chemistry teachers' competence.

STEM is expected to accommodate changes in social, cultural, and economic demands that continuously occur in society. Therefore, educational patterns must be adjustable. Chemical materials, such as colloids and polymers, are possibly experimented with to produce economically valuable products, such as laundry soap, fertilizers, and organic plastics. Therefore, students can participate in driving economic growth by preparing their skills even though they are learning in public schools. It is a fact that the number of the community's most consumed products, such as plastics, are impossibly decreased; still, students can modify the products by creating more environmentally friendly ones, such as bioplastics or wooden materials including cassava peels (Wahyuningtiyas \& Suryanto, 2017). This type of learning will increase the students' literacy towards the environment, boost morale, and improve concerns for society's problems (Permanasari, 2016). Suppose the future teaching process has 
insufficient educational facilities, such as the internet and laboratories. In that case, creative educators can still cover this insufficiency by employing the science of technology, pedagogy, engineering science, good communication, mastery of the material, and adequate mathematical calculations. Hence, it is evident that prospective teachers must readily implement STEM education as a solution to encounter the era (Chai, 2018). However, there have not been many systematic and empirical studies investigating prospective chemistry teachers' knowledge of the STEM-based learning concept and its implementation strategies. Therefore, this research focuses on these two problems.

\section{Method}

This research employed a descriptive analysis method with a quantitative approach. The researchers collected data by distributing questionnaires and tests. This study's population was 125 students of the Chemistry Education Department, Faculty of Teacher Training and Education, Syiah Kuala University, Banda Aceh. The population had attended the apprenticeship course. The Chemistry Education Department was selected by considering its A accreditation, the university's A accreditation, and the oldest university in Aceh Province.

Meanwhile, the population must meet the criterion of passing the apprenticeship because it considers them as professionally competent teachers. Therefore, it is expected that they can provide relevant information following research problems. This research population was 125 people and received an online questionnaire-however, only 69 of them responded and willingly participated as the research sample. Thus, the total samples were more than $50 \%$ of the population.

The procedures of this research included three stages: preparation, implementation, and data processing. The first stage of this research was preparation by making student knowledge instruments for implementing STEM education-based learning. Subsequently, this instrument was validated and revised for use. The next stage was implementing an online questionnaire to the research samples and explaining the research objectives and instruments to fill in the instruments. Finally, the collected data were processed and analyzed to conclude.

The data collection flowchart started from problem observation, literature study, determination of sample criteria, instrument development, instrument validation, instrument revision, instrument testing, data collection, data analysis, discussion, and conclusions. The criterion validity of the questionnaire referred to a theory by Akbar (2013). The validity level 
was presented in numerical percentages from the total of valid items and the sum of validated instrument items. The validation results were revised according to the validator's inputs and pointed out that all of the instruments were valid.

This research employed a quantitative descriptive analysis to investigate chemistry students' knowledge of applying STEM education-based learning. The collected data, including means and standard deviations of each item, were analyzed using a descriptive analysis technique.

Table 1. Categorization of students' knowledge of implementing STEM-based learning

\begin{tabular}{cc}
\hline STEM scores $(\mathbf{X})$ & Categories \\
\hline $\mathrm{X} \geq$ Mean $+1 \mathrm{SD}$ & High \\
Mean $-1 \mathrm{SD} \leq \mathrm{X}<$ Mean $+1 \mathrm{SD}$ & Moderate \\
$\mathrm{X}<$ Mean $-1 \mathrm{SD}$ & Low \\
\hline
\end{tabular}

(Azwar, 2010)

$\mu=$ mean, with the formula $\mu=(\max$ score $+\min \operatorname{score}) / 2 ; \sigma=$ standard deviation, with the formula $\sigma=(\max$ score $-\min$ score $) / 6$. After a clear categorization is determined, the percentage in each category is calculated and then interpreted. The grouping interpretations of the mean scores of each STEM knowledge domain are presented in Table 2.

Table 2. Categorization of values of each STEM knowledge domain

\begin{tabular}{cc}
\hline Average Scores of STEM domains & Categories \\
\hline $1.00-1.50$ & Low \\
$1.51-2.50$ & Enough \\
$2.51-3.50$ & Moderate \\
$3.51-4.00$ & High
\end{tabular}

(Kamila, 2017)

Furthermore, the interpretation of categorizing the average domain values of students' knowledge of applying STEM-based learning is presented in Table 3.

Table 3. Categorization of domain values of students' knowledge of applying STEM-based learning

\begin{tabular}{cc}
\hline Average scores of STEM domains & Categories \\
\hline $0.00-25.00$ & Low \\
$25.01-50.00$ & Enough \\
$50.01-75.00$ & Moderate \\
$75.01-100$ & High \\
\hline
\end{tabular}

(Kamila, 2017)

The questionnaire was divided into two types of responses: 18 statement items and ten questions discussing a new product case. The expert validation revealed that there were no 
changes in the 18 questionnaire items, but the validators improved the language used in some statement items. The score of questionnaire items was $94.44 \%$ was considered very valid. Furthermore, the expert validation improved types of questions, particularly answer choices for the evaluation questions. The score of the types of questions was $95 \%$ and was considered very valid.

This research's data processing included a stage of the normality test using the Kolmogorov-Smirnov (KS Z) technique. The test result is considered normal if the significant value is $>0.05$. If the data is normally distributed, the next analysis technique can employ the parametric statistical method; whereas if the data is not normally distributed, the following analysis technique can use the nonparametric statistical method (Dahlan, 2008). Furthermore, the homogeneity test that discovers data similarity of the population variance is considered homogeneous if the sig value is $>0.05$; on the other hand, it is considered different if the significant value is $<0.05$ (Priyatno, 2011). The homogeneity test is calculated by comparing the largest and the smallest variants. The results of the research instrument test were discussed in the discussion session.

\section{Result and Discussion}

This research collected data through a questionnaire consisting of statements and a test consisting of case-based questions. The instruments of this research were divided into three components of students' knowledge of STEM-based learning: conceptual, learning process, and indicators of successful STEM-based learning. Meanwhile, knowledge of the strategy for implementing STEM-based learning was divided into three components: integrated disciplines (science, technology, engineering, and mathematics), applied knowledge (planning, implementing, and evaluating), and soft skills (creativity and innovation, communicative, and collaborative). The questionnaire statements employed a Likert scale with four response options: strongly disagree, disagree, agree, and strongly agree. The domain distribution of the questionnaire statements is presented in Table 4.

Table 4. Distribution of STEM questionnaire statements

\begin{tabular}{ccc}
\hline No. & STEM knowledge domains & Statement item numbers \\
\hline 1 & Term & $1,2,3,4,5,6$, \\
2 & Implementation of learning & $7,8,9,10,11,12$ \\
3 & Indicators of successful learning & $13,14,15,16,17,18$ \\
\hline
\end{tabular}


The test was in the form of multiple-choice questions and consisted of four answer choices. The domain distribution of the questionnaire questions is presented in Table 5.

Table 5. Distribution of STEM questions

\begin{tabular}{ccc}
\hline No. & STEM-Based learning knowledge domains & Question item numbers \\
\hline 1 & Aspects (science, technology, engineering, and mathematics) & $1,2,3,4$ \\
2 & Planning, implementation, and evaluation & $5,6,7$ \\
3 & Creativity and innovation, communicative, and collaborative & $8,9,10$ \\
\hline
\end{tabular}

The result of instrument validation reveals that the feasibility value is very valid by $92.7 \%$. Then, trials on 12 prospective chemistry teachers aim to discover if the respondents can easily understand each question and language used and can 100\% comprehend the questions' purposes. The respondent distribution is presented in Table 6

Table 6. Distribution of demographic data on prospective chemistry teachers

\begin{tabular}{ccccc}
\hline No. & Characteristics & Distribution & F & $(\boldsymbol{\%})$ \\
\hline 1 & GPA & $2.46-3.39$ & 25 & 36.2 \\
& & $3.40-3.61$ & 22 & 31.9 \\
& & $3.62-3.85$ & 22 & 31.9 \\
2 & Has attended an internship course & Yes & 69 & 100 \\
& & Not & 0 & 0.00 \\
\hline
\end{tabular}

The normality test technique of this study was the Kolmogorov-Smirnov using the SPSS program. The results of the normality test reveal the KSZ value $=0.79$ or significant $p=0.200$ $>0.05$. These indicate that the distribution of this research is normal. Meanwhile, the significance value of the homogeneity test was $p=0.585>0.05$, and it suggests that the data distribution of this research has the same variants.

The data of prospective chemistry teachers' knowledge of implementing STEM-based learning were analyzed descriptively. The respondents' knowledge of applying STEM-based learning was gained after analyzing their conceptual knowledge of STEM. Hypothetical data used for categorical boundaries are low, medium, and high categories. The data reveal the categories of students' knowledge of STEM. These categories are presented in Table 7.

Table 7. Results of categorizing the students' knowledge of STEM

\begin{tabular}{ccccc}
\hline \multicolumn{2}{c}{ STEM knowledge scores $(\mathbf{X})$} & $\begin{array}{c}\text { STEM knowledge } \\
\text { categories }\end{array}$ & \multicolumn{2}{c}{ Number of students } \\
\hline $\mathrm{X}<$ Mean $-1 \mathrm{SD}$ & $\mathrm{X}<38.29$ & Low & 1 & $\mathbf{( \% )}$ \\
\hline Mean $-1 \mathrm{SD} \leq \mathrm{X}<$ Mean $+1 \mathrm{SD}$ & $38.29 \leq \mathrm{X}<51.71$ & Moderate & 16 & 23.45 \\
$\mathrm{X} \geq$ Mean +1 SD & $\mathrm{X} \geq 51.71$ & High & 52 & 75.27 \\
\hline
\end{tabular}


Table 7 indicates that one person (1.45\%) has a low category, 16 people $(23.28 \%)$ have a medium category, and 52 people $(75.27 \%)$ have a high category. These results indicate that the frequency of students with high STEM knowledge category is the largest of other categories. The domain of students' knowledge of STEM is presented in Table 8.

Table 8. Descriptive statistics of students' knowledge of STEM

\begin{tabular}{cccc}
\hline STEM knowledge domains & Average scores & Frequency (\%) & Categories \\
\hline Conceptual aspects (STEM term) & 3.49 & 87.25 & Moderate \\
Knowledge of the STEM-based learning process & 2.81 & 70.25 & Moderate \\
Indicators of successful STEM-based learning & 3.03 & 75.75 & Moderate \\
\hline
\end{tabular}

Table 8 shows that the highest distribution of the knowledge domain is the conceptual STEM, followed by successful STEM and STEM-based learning indicators. This result concludes that students' knowledge of STEM is in the medium category by $3.11(77.75 \%)$. It occurs because STEM is one of the new learning approaches in the 4.0 era that emphasizes the integration of four STEM fields: science, technology, engineering, and mathematics or at least two of them; STEM also demands innovation, creativity, productivity, communication, collaborative learning, writing proficiency, knowledge of technology literacy, mathematics, and science. These competencies are necessarily demanded to work and globally compete in the recent era (Bergeron \& Gordon, 2017). Because STEM-based learning is relatively new in Aceh, it has not been implemented directly. The training in STEM-based learning has only been implemented once by the Aceh Provincial Education Office in Aceh in collaboration with the Aceh Education Quality Assurance Agency. Furthermore, since the STEM-based learning has not been widely implemented, the students show low scores in the knowledge of STEM-based learning process and indicators of successful STEM-based learning.

Prospective chemistry teachers are future educators who will create more improved education. One of the strategies to improve the quality of education is applying STEM-based chemistry learning. Content knowledge, pedagogy, and fair evaluation in implementing learning will undoubtedly affect the desired outcomes. Nowadays, educators must improve their technology literacy because the teaching and learning process positively engage with internet learning media (Kelley \& Knowles, 2016). As prospective teachers born in the modern technology era, the students must be familiar with STEM aspects. The score of prospective chemistry teachers' knowledge of applying STEM-based learning is presented in Table 9. 
Table 9. The results of the categorizing students' knowledge of applying STEM-based learning

\begin{tabular}{ccccc}
\hline $\begin{array}{c}\text { Scores for knowledge of applying STEM-based } \\
\text { learning }(\mathbf{X})\end{array}$ & Knowledge categories & \multicolumn{2}{c}{ Numbers of students } \\
\cline { 3 - 5 } & & Low & F & 1.45 \\
\hline $\mathrm{X}<$ Mean - 1 SD & Moderate & 34 & 49.275 \\
Mean - 1SD $\leq \mathrm{X}<$ Mean + 1SD & $38.29 \leq \mathrm{X}<51.71$ & High & 34 & 49.275 \\
$\mathrm{X} \geq$ Mean + 1 SD & $\mathrm{X} \geq 51.71$ & & \\
\hline
\end{tabular}

Table 9 shows that the students with moderate knowledge category are as many as the students with high knowledge category, that is 34 students (49.275\%). Meanwhile, only one student $(1.45 \%)$ has a low category. Overall, the prospective chemistry teachers' average knowledge of applying STEM-based learning is in the moderate category by $65.22 \%$. This result agrees with the curriculum system of teacher education that has not trained the students to practice STEM-based learning. Furthermore, the curriculum has not included STEM-based courses or STEM-based teaching practices. In general, the students' knowledge of implementing STEM is in the moderate category. However, they also show different level categories, such as the enough and high category as presented in Table 10.

Table 10. Descriptive statistics of students' knowledge of applying STEM-based learning

\begin{tabular}{ccc}
\hline $\begin{array}{c}\text { The domain of knowledge about STEM } \\
\text { implementation strategy }\end{array}$ & $\begin{array}{c}\text { Average score versus } \\
\text { maximum score } \mathbf{( \% )}\end{array}$ & Category \\
\hline Science & 89.86 & High \\
Mathematics & 34.78 & Enough \\
Technology & 73.91 & Moderate \\
Engineering & 46.38 & Enough \\
Planning & 49.28 & Enough \\
Implementation & 49.28 & Enough \\
Evaluation & 63.77 & Moderate \\
Creativity \& Innovation & 57.97 & Moderate \\
Communication & 98.55 & High \\
Collaboration & 88.41 & High \\
\hline
\end{tabular}

Table 10 shows that the students' lowest knowledge score of strategies for implementing STEM-based learning is in mathematics by 34.87 or in enough category. This result indicates that mathematics is a difficult subject for students. Many factors cause this difficulty: common basic knowledge of mathematics, low learning motivation, complex topics, and complex numbers. These problems possibly disturb prospective chemistry teachers. 
Moreover, chemistry is one of the issues in science that is inseparable from mathematics because many chemistry materials require mathematical formulations to solve chemical cases, such as measuring particles of an atom, pH of an acid, or base (Restrepo \& Villaveces, 2012; Gladys et al., 2017). STEM is an approach that offers mathematical literacy. In the process of implementing STEM-based learning, especially when creating a quality product from planning to evaluation, good mathematical calculation skills are necessary. If an educator does not have the mathematical calculation knowledge, he will find it challenging to assess and evaluate the students' mathematical processes (Chai, 2018).

The second-lowest position of students' knowledge of implementing STEM-based learning is in engineering by 46.38 or in enough category. Engineering in STEM-based learning is a process of creating and innovating a new product. The respondents' answers on enough category and multiple-answer questions conclude that most students do not understand the role of engineering in STEM as a process of creating a product. However, this knowledge is adaptable for the students because, as prospective chemistry teachers, they frequently work in the chemistry learning practicum (Kelley \& Knowles, 2016).

Meanwhile, knowledge of planning and knowledge of implementation is in the third lowest position by 49.28 or in enough category. This result occurs because only a few respondents made a lesson plan and implemented STEM-based learning when attending an internship. Therefore, some of the respondents who did not implement STEM-based learning were confused with determining answers. Chemistry students have learned to plan and implement a learning process from several subjects, such as lesson plans, teaching and learning strategies, and internships. However, apart from that, designing and implementing a STEM-based teaching and learning process must recognize the syntax of STEM (Carter, 2013). Table 10 shows the students' lowest knowledge score of strategies for implementing STEM-based learning in mathematics by 34.87 or in enough category.

The score of the creativity and innovation domain is 57.97 or in the medium category. This domain is critical to assist in the implementation of STEM-based learning. Creativity and innovation to create a new product are essential, especially when it offers solutions to environmental problems. The creativity and innovation used in STEM-based learning are inseparable from the STEM process flows. This domain score can be more excellent if the respondents understand well the ideal STEM-based learning (Hyford et al., 2015). 
The knowledge score of the evaluation domain is 63.77 or in the medium category. Although the evaluation is in the same category as the planning and implementation, this domain has a higher score. This result concludes that students' knowledge of STEM-based learning is better than their planning and implementation. STEM-based learning evaluation is critical to ensure the integration of STEM components. This integration can minimize errors that occur in the future learning process (Septiani \& Rustaman, 2017).

The following domain is the technology of which the value is 73.91 or in the medium category. This score is pretty good for this domain and positively relates to all of the prospective chemistry teachers who were born in the technology era. Today, almost all students can properly operate technology and communication tools, such as computers, smartphones, IOS, and android. Moreover, many of them understand the work of a processor, excellently surf the internet, and use complicated application software, for example, Photoshop. This application requires special skills to run it. Besides, technology literacy is obtained through the lecture process by applying technology tools. The technology domain in STEM-based learning refers to new technology tools that assist the process of creating new products. This knowledge is essential for prospective chemistry teachers in determining their attitudes towards the technology used; therefore, they can easily understand chemical materials through several techniques, such as demonstrations, simulations, or indirect practices (Sa'adah \& Kariadinata, 2018).

Meanwhile, the domains that have high categories are collaboration (88.41), communication (98.55), and science (89.86). Comprehensive understanding of science, especially chemistry, is essential for the curriculum demands to provide students' group discussion during the class that has increased their collaboration and communication skills while completing tasks. One example of teamwork frequently conducted is a practicum in the laboratory. Practical activities train students how to solve real problems and sometimes trigger the appearance of small determinations through mutual agreement, such as distributing work tasks to each member and determining leadership, minutes, or a spokesperson to evaluate team performance and shape students' collaboration skills. These activities agree with the improvement of students' communication ability. Applying STEM-based learning demands good communication skills, the ability to convey the STEM-based learning approach to students, and the assessment of students' communication skills from the prospective chemistry teachers. Furthermore, this application demands prospective chemistry teachers' 
advanced communication skills in explaining the STEM-based learning approach to the students, assessing their communicative competence, presenting manufactured products, solving problems, and clarifying reasons for a method selection (Hyford et al., 2015; Schmidt et al., 2009; Sang et al., 2014; Jang \& Tsai, 2012; Lin et al., 2014).

The most dominant characteristic of STEM-based learning is the integration of science, technology, engineering, and mathematics. This integration is essential for prospective chemistry teachers to select suitable chemistry materials to integrate science, technology, engineering, and mathematics with other STEM domains. Low mastery of chemistry concepts disables students to achieve a learning goal because they select the wrong technology, technique, and calculation for the offered products. However, the students' domain of science is in the high category. This result indicates that optimally applying STEM-based chemistry learning is beneficial for students (Kelley and Knowles, 2016).

\section{Conclusion}

The majority of chemistry education students of the Faculty of Teacher Training and Education who took the internship program have a moderate level of conceptual knowledge of STEM implementation strategies. Students already know and have conceptual knowledge of STEM but still have inadequate knowledge of the process and indicators of STEM-based learning. The investigation of students' knowledge level of strategies for implementing STEM-based learning indicates that they have a high level in science application strategy, communication, and collaboration. Still, they show low level in other fields of science. Furthermore, they have a low level of knowledge of planning, implementation, evaluation, and creativity and innovation in implementing STEM. Even though this research object is still limited to chemistry education students of the Faculty of Teacher Training and Education who took an internship program, the results are possibly generalized to all Indonesian areas. This possibility occurs because the curricula of nearly all chemistry education departments have not inserted science integration. The monodisciplinary curriculum can contribute to the mastery of the monodisciplinary concepts. However, graduates perhaps cannot integrate science and mathematics that characterize technological development and real problems in society. Therefore, STEM is necessarily included in the curriculum. 


\section{Acknowledgements}

The authors would like to thank the instrument validators, who provided many suggestions for improving these research instruments. Moreover, the authors would like to thank the supervisors and examiners for formal seminar forums and informal communication. Finally, the authors would like to thank the respondents who willingly filled in the online questionnaire and actively participated in online interviews to confirm information.

\section{References}

Adlim, M., Saminan., \& Ariestia, S. (2015). Pengembangan modul STEM terintegrasi kewirausahaan untuk meningkatkan keterampilan proses sains di SMA Negeri 4 Banda Aceh. Jurnal Pendidikan Sains Indonesia, 3(2), 112-121.

Afriana, J., Permanasari, A., \& Fitriani, A. (2016). Penerapan project based learning terintegrasi STEM untuk meningkatkan literasi sains siswa ditinjau dari gender. Jurnal Inovasi Pendidikan IPA, 2(2), 202-212.

Akbar, S. (2013). Instrumen peragkat pembelajaran. Remaja Rosdakarya.

Al Salami, M. K., Makela, C. J., \& de Miranda, M. A. (2017). Assessing changes in teachers' attitudes toward interdisciplinary STEM teaching. International Journal of Technology and Design Education, 27(1), 63-88.

Azwar, S. (2010). Penyusunan skala psikologi. Pustaka Pelajar.

Bell, D. (2015). The reality of STEM education, design, and technology teachers' perception of a phenomenographic study. International Journal of Technology and Design Education, 26(1), 61-79.

Bergeron, L. \& Gordon, M. (2017). Establishing a STEM pipeline: trend in male and female enrollment and performance in higher-level secondary STEM courses, International Journal of Science and Mathematics Education, 15, 433-450.

Carter, R. (2013). Defining characteristics of an integrated STEM curriculum in K-12 education. Published doctor dissertation) University of Arkansas, Fayetteville.

Chai, S. C. (2018). Teacher professional development for science, technology, engineering, and mathematics (STEM) education: A review from the perspectives of technological pedagogical content (TPACK). Asia-pacific Education Research, 28(1), 5-13.

Dahlan, M. S. (2008). Statistik untuk kedokteran dan kesehatan. Salema Medika.

Farwati, R., Permanasari, A., Firman, H., \& Suhery, T. (2018, March). Integrasi problem based learning dalam STEM education berorientasi pada aktualisasi literasi lingkungan dan kreativitas. In Seminar Nasional Pendidikan IPA (Vol. 1, No. 1, pp. 198-206).

Gladys, C, O., Arokoyu, A. A., \& Joseph, A. C. (2017). Effect of mathematics knowledge on chemistry students' academic performance in gas law. European Journal of Mathematics and Computer Science, 4(1), 1-6.

Guoyon, S., Tondeur, J., Chai, C. S., \& Dong, Y. (2014). Validation and profile of Chinese pre-service teachers' technological pedagogical content knowledge scale. Asia-Pacific Journal of Teacher Education, 44, 49-65.

Hyford, B., Blomstrom, S., \& Mumpower, L. (2015). Formation and assessment of a tool to evaluate STEM. Journal on Excellence in Collage teaching, 26(4), 73-101. 
Ismail, I., Permanasari, A., \& Setiawan, W. (2016). Efektivitas virtual lab berbasis STEM dalam meningkatkan literasi sains siswa dengan perbedaan gender. Jurnal Inovasi Pendidikan IPA, 2(2), 190-201.

Jang, S. J., \& Tsai, M. F. (2012). Exploring the TPACK of Taiwanese elementary mathematics and science teachers with respect to the use of interactive whiteboards. Computers \& Education, 59(2), 327-338.

Kamila, I. N. (2017). Perbedaan kinerja mengajar guru pendidikan anak usia dini ditinjau dari latar belakang pendidikan. Tunas Siliwangi, 3(1), 38-56.

Kelley, T., \& Knowles, J. G. (2016). A conceptual framework for integrated STEM education. International Journal of STEM Education, 3(11), 2-11.

Lin, T. C., Tsai, C. C., Chai, C. S., \& Lee, M. H. (2013). Identifying science teachers' perceptions of technological pedagogical and content knowledge (TPACK). Journal of Science Education and Technology, 22(3), 325-336.

Permanasari, A. (2016, October). STEM education: Inovasi dalam pembelajaran sains. In Seminar Nasional Pendidikan Sains VI 2016. Sebelas Maret University.

Pimthong, P., \& Williams, J. (2018). Preservice teacher understanding of STEM education. Kasetsart Journal of Social Sciences, 16(2), 1-7.

Priyatno, D. (2011). Buku saku SPSS analisis statistika data lebih cepat, lebih efisien dan akurat. Mediakom.

Rahmiza, S., Adlim, M., \& Mursal. (2015). Pengembangan LKS STEM (science, technology, engineering, and mathmematics) dalam meningkatkan motivasi dan aktivitas belajar siswa SMA Negeri Beutong pada materi induksi elektro magnetik. Jurnal Pendidikan Sains Indonesia, 3(1), 239-250.

Restrepo, G., \& Villaveces, J. L. (2012). Mathematical thinking in chemistry. Hyle: International Journal for Philosophy of Chemistry, 18(1), 3-22.

Sa'adah, S., \& Kariadinata, R. (2018). Profil technological pedagogical and content knowledge mahasiswa calon guru biologi. Jurnal Program Studi Pendidikan Biologi, 8(2), 17-28.

Sang, G., Tondeur, J., Chai, C. S., \& Dong, Y. (2014). Validation and profile of Chinese preservice teachers' technological pedagogical content knowledge scale. Asian-Pacific Journal of Teacher Education, 44(1), 49-65.

Sari, R. P., Adlim, M., \& Gani, A. (2018, September). STEM learning in regular and vocational high schools on the topic of scientific menu card fabrication. In Journal of Physics: Conference Series (Vol. 1088, p. 012114).

Schmidt, D. A., Baran, E., Thompson, A. D., Mishra, P., Koehler, M. J., \& Shin, T. S. (2009). Technological pedagogical content knowledge (TPACK): The development and validation of an assessment instrument for preservice teachers. Journal of Research on Technology in Education, 42(2), 123-149.

Septiani, A., \& Rustaman, N. Y. (2017, February). Implementation of performance assessment in STEM (Science, Technology, Engineering, Mathematics) education to detect science process skill. In Journal of Physics: Conference Series (Vol. 812, No. 1, p. 012052).

Wahyuningtiyas, N. E., \& Suryanto, H. (2017). Analysis of biodegradation of bioplastics made of cassava starch. Journal of Mechanical Engineering Science and Technology, 1(1), 24-31. 